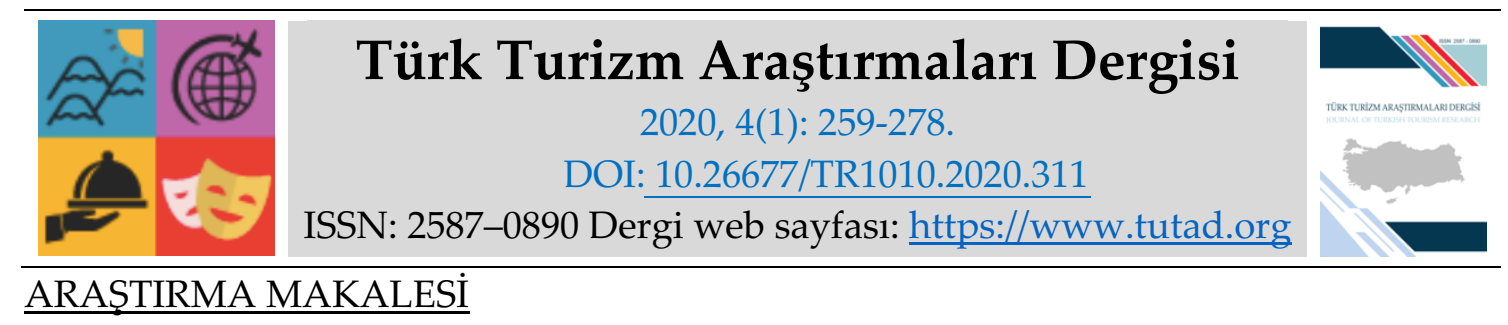

\title{
Turizm İşletmelerinde Hizmet Hataları ve Hizmet Telafisi Yöntemlerinin Müşteri Memnuniyeti Üzerindeki Etkisi: Bir Uygulama
}

Dr. Öğr. Üyesi İnci ERDOĞAN TARAKÇı, Bilecik Şeyh Edebali Üniversitesi, Sağlık Bilimleri Fakültesi, Bilecik, e-posta: inci.erdogan@bilecik.edu.tr

ORCID: https://orcid.org/0000-0002-4101-7111

Dr. Öğr. Üyesi Bora GÖKTAŞ, Bayburt Üniversitesi, Uygulamalı Bilimler Fakültesi, Bayburt, eposta: boragoktas@bayburt.edu.tr

ORCID: https://orcid.org/0000-0003-2159-0241

\section{Öz}

Hizmet sektörünün yapısı gereği hizmet hataları ile sıklıkla karşılaşılmaktadır. Bu hataların kaynağ bazen işletmenin kendisi, bazen personel, bazen diğer müşteriler ve hatta müşterinin kendisi olabilmektedir. İşletmeler, kaynağı ne olursa olsun hizmet hatalarının sorumlusunu bulmak, telafi etmek ve tekrarlanmaması için önlemler almak durumundadır. Özellikle faaliyetleri tüm yıl boyunca aralıksız devam etmekte olan turizm işletmeleri için tüketicilerdeki hizmet kalitesi algısının arttırılması müşteri memnuniyetinin sağlanması açısından oldukça önemlidir. Bu çalışmada, yarattı̆̆ katma değer büyüklüğü ile tüm hizmet sektörleri içerisinde ön plana çıkan turizm işletmelerinde tüketicilerin karşılaştıkları hizmet hatalarının oranı, sıklığı, türü, kaynağı, tüketicilerin gösterdikleri tepki, işletmelerin uyguladıkları hizmet telafisi yöntemleri ve bu yöntemlerin etkinliği belirlenmeye çalışılmıştır. Aynı zamanda hizmet telafisi uygulaması sonrasında müşteri memnuniyetinde ve algısında meydana gelen değişimler ve hizmet hatalarının tüketici tercihleri üzerindeki etkisi ortaya konulmaya çalışılmıştır. Bu amaçla internet ortamında 394 tüketiciye anket uygulanmış, hiç hizmet hatası ile karşılaşmamış olan 7 katılımcıya ait anketler elenerek toplamda 387 anket sınamaya alınmıştır ve çalışan hataları ile işletme yönetiminin yaptığı hataların müşteri memnuniyetsizliği yaratmada daha etkili olduğu görülmüştür. Ayrıca bu hatalar neticesinde oluşan müşteri memnuniyetsizliğinin giderilmesinde hatayı telafi etme çabalarının (odaya yemek gönderme, indirim yapma, ücretsiz akşam yemeği, armağanlar sunma, hizmetin ücrete tabi olanaklarından ücretsiz faydalanma gibi çabalar) özür dileme, açıklama yapma, sorun giderme gibi çabalardan daha etkili olduğu da görülmüştür.

Anahtar Kelimeler: Hizmet Hataları, Hizmet Telafisi, Turizm Sektörü, Müşteri Memnuniyeti, Tüketici Davranışları.

Makale Gönderme Tarihi: 06.10.2019

Makale Kabul Tarihi: 08.01.2020

Önerilen Atıf:

Erdoğan Tarakçı, İ. ve Göktaş, B. (2020). Turizm İşletmelerinde Hizmet Hataları ve Hizmet Telafisi Yöntemlerinin Müşteri Memnuniyeti Üzerindeki Etkisi: Bir Uygulama, Türk Turizm Araştırmaları Dergisi, 4(1): 259-278.

(C) 2020 Türk Turizm Araştırmaları Dergisi. 


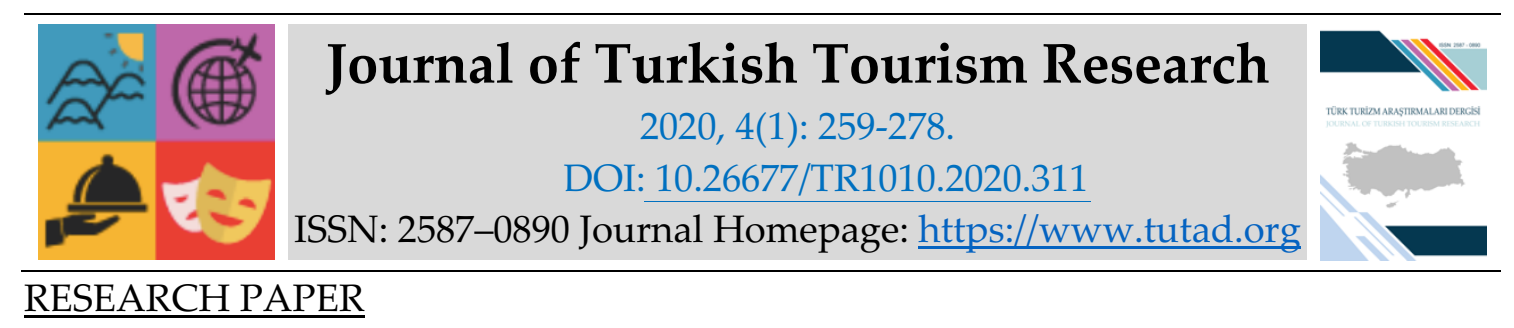

\title{
The Effect of Service Failures and Service Recovery Methods on Customer Satisfaction in Tourism Enterprises: An Application
}

Assistant Prof. Dr. İnci ERDOĞAN TARAKÇI, Bilecik Şeyh Edebali University, Faculty of Health Sciences, Bilecik, e-mail: inci.erdogan@bilecik.edu.tr

ORCID: https://orcid.org/0000-0002-4101-7111

Assistant Prof. Dr. Bora GÖKTAŞ, Bayburt University, Faculty of Applied Sciences, Bayburt, email: boragoktas@bayburt.edu.tr

ORCID: https://orcid.org/0000-0003-2159-0241

\begin{abstract}
Due to the nature of the service sector, service failures are frequently encountered. The source of these failures can sometimes be the company itself, sometimes the staff, sometimes other customers and even the customer itself. Businesses have to find, compensate and take measures to prevent the recurrence of service failures regardless of their source. Increasing the perception of service quality in consumers is very important in terms of ensuring customer satisfaction especially for tourism enterprises whose activities continue continuously throughout the year. In this study, the rate, frequency, type and source of service failures encountered by consumers in tourism enterprises that stands out among all service sectors with the added value it has created; consumer reactions; service recovery methods applied by enterprises and effectiveness of these methods were tried to determine. At the same time, the changes in customer satisfaction and perception after the service recovery application and the effect of service failures on consumer preferences were tried to be revealed. For this purpose, 394 consumers were surveyed on the internet and the surveys of 7 participants who had never encountered service errors were eliminated and a total of 387 questionnaire data were analyzed and it was seen that employee failures and mistakes made by the company management are more effective in creating customer dissatisfaction. In addition, it was observed that the efforts to compensate for the customer dissatisfaction resulting from these failures (such as sending food to the room, making discounts, giving free dinner, offering gifts, making use of the service's charge-free facilities) were more effective than apologizing, explaining and troubleshooting.
\end{abstract}

Keywords: Service Failures, Service Recovery, Tourism Sector, Customer Satisfaction, Consumer Behavior. Received: 06.10.2019

Accepted: 08.01.2020

\footnotetext{
Suggested Citation:

Erdoğan Tarakçı, İ. and Göktaş, B. (2020). The Effect of Service Failures and Service Recovery Methods on Customer Satisfaction in Tourism Enterprises: An Application, Journal of Turkish Tourism Research, 4(1): 259278.

(C) 2020 Türk Turizm Araştırmaları Dergisi.
} 


\section{GİRIŞ}

Hizmetlerin yapısı gereği hizmet hataları sıklıkla yaşanmaktadır. Hizmet hatalarının ortaya çıktığı durumlarda işletmelerin sergilediği tutum ve davranışlar, müşterilerin satın alma davranışları üzerinde oldukça büyük etkiye sahiptir.

Her sektörde olduğu gibi turizm sektöründe de müşteri memnuniyeti sadık müşteri elde etmek açısından oldukça önemlidir. Eksik veya hatalı sunulan hizmetlerden dolayı müşterilerde oluşan kötü itibar doğru hizmet telafisi yöntemlerinin uygulanması ile değiştirilebilmekte, yaşanılan dezavantajlı durum avantaja dönüştürülebilmektedir. Diğer yandan özellikle rekabetin oldukça yoğun olduğu turizm işletmelerinde uygulanacak yetersiz ya da hatalı telafi yöntemleri, zaten memnuniyetsiz olan müşterilerin yaşadıkları memnuniyetsizliği pekiştirmekte ve tepkilerini daha sesli hale getirmektedir. Bu durum işletmenin imajını da olumsuz yönde etkileyecektir.

Literatürde hizmet hatalarının müşteri memnuniyetine etkisi üzerine yapılmış birçok çalı̧̧ma (Cinar ve Koc, 2018; Stratemeyer vd., 2014; Lii vd., 2012; Iglesias, 2009 gibi) mevcuttur. Bu çalışmaların bir kısmı telafi yöntemlerinin etkili uygulandığı durumlarda elde edilecek müşteri memnuniyetinin hiç hizmet hatasının gerçekleşmediği durumlara kıyasla daha yüksek olacağını destekler nitelikteyken (Mattila, 1999; Tax vd., 1998; Smith ve Bolton, 1998; Eccles ve Durand, 1998; Spreng vd., 1995; Hart vd., 1990). Aynı şekilde Özdemir ve Avcı (2019), Kambur (2018), Keiningham vd., (2014) ve Çalışkan (2013) da yaptıkları çalışmalarda hizmet hataları sonucu tatminsiz olan müşterinin etkili hizmet telafisi yöntemleri ile tatmin edilebileceğini ve böylece işletmenin imajının da olumlu etkileneceğini vurgulamaktadır. Keiningham vd., (2014) hizmet telafisinin temel amacının tatminsizlik yaşayan müşterinin tatmin edilmesi olması gerektiğini vurgularken, Kambur (2018) hizmet telafisi yönteminin etkinliğinin müşteri tatmini üzerindeki büyük etkisine dikkat çekmekte, Çalışkan (2013) bu konuda asıl görevin üst yönetime düştügüunü vurgularken memnuniyetsizlik yaşamış bir müşterinin etkili hizmet telafisi uygulamaları ile yeniden memnun edilip işletmeye yeniden gelmesinin sağlanabileceğini ifade etmekte, Özdemir ve Avcı (2019) ise etkili hizmet telafi yöntemlerinin aynı zamanda işletmenin imajını da önemli ölçüde olumlu olarak etkileyeceğini öne sürmektedir.

Çalışmaların bir kısmı da herhangi bir telafi yönteminin uygulanmasının hiçbir telafi yönteminin uygulanmamasından daha iyi olacağını savunmaktadır (Kim ve Jang, 2014; Noone, 2012; Warden vd., 2008; Hocutt vd., 2006; Cranage, 2006; Mattila ve Patterson, 2004; Warden vd., 2003; Liu vd., 2001; Gordon vd., 1999). Çalışmaların bir kısmı etki düzeyi yüksek telafilerin müşteri memnuniyeti yaratacağını savunmakta (Çalışkan, 2013; Ha ve Jang, 2009; Tsai ve Su, 2009; Kim vd., 2009; Fu ve Mount, 2007; Hocutt vd., 2006; Lewis vd., 2004; Smith vd., 1999;) ve bir k1smı ise bu görüşlerin aksine telafilerin müşteri memnuniyetini sağlamakta yetersiz kaldığını (Chua vd., 2010; Hoffman vd., 1995), hiçbir telafi yönteminin tek başına yeterli olamayacağını, müşteri memnuniyetinin mümkün olabileceği durumlarda dahi bunun ancak birden fazla telafi yönteminin birlikte kullanılması ile sağlanabileceğini savunmaktadır (Zulhan vd., 2013; Wirtz ve Mattila, 2004).

Bu çalışmada, turizm işletmelerinde müşterilerin yaşadıkları hizmet hatalarının sıklığı, türü, kaynağı, hizmet hataları karşısında işletmelerin uyguladıkları telafi yöntemleri ve işletmelerin tutumları, telafi yöntemlerinin etkinliği ve telafi sonrası müşteri memnuniyetinin değişip değişmediği araştırılmıştır. 


\section{HIZMET HATALARI}

Hizmet hataları, hizmet temin zincirinde herhangi bir noktada meydana gelen bir başarısızlık sebebiyle ürünün müşterinin beklentilerini karşılamakta yetersiz kalması olarak tanımlanmaktadır (Mueller vd., 2003:1780). Hizmet hataları, hizmetlerin sunumu esnasında algilanan hizmet kalitesinin müşterinin beklentisinden daha düşük seviyede olduğu durumlarda ortaya çıkmaktadır. Li, Li ve Peng (2011) hizmet hatasını tüketim sürecinde tüketicilerin memnuniyetsizlik yaşamasına sebep olan durum olarak tanımlamaktadır. Palmer'a (2001) göre ise hizmet hatası, gerçekte olan ya da müşterinin algıladığı hizmet sorunları veya işletme ile ilgili yaşanılan kusurları ifade etmektedir. Hizmet hataları, müşteri memnuniyetsizliğinin en temel belirleyicilerinden birisidir. Tüketicilerin hizmet hatalarından dolayı yaşadıkları olumsuz tecrübeler ve hissettikleri memnuniyetsizlik tüketicinin karar verme sürecinde davranış değiştirmesine neden olacak ve dolayısıyla tüketici karar verme sürecini yönlendirecektir.

Hizmet hatalarının ortaya çımasında etkili olan birçok neden vardır. Bozkaya (2012:47) bu nedenleri üç temel başlıkta toplamaktadır. Bunlar;

$\checkmark$ Koordinasyon İhtiyac1,

$\checkmark$ Emek Yoğunluğu,

$\checkmark$ Kontrol Edilemeyen Koşulların Sıklığıdır.

Hizmetlerin yapısı gereği hizmet işletmelerinde yürütülen faaliyetlerin koordinasyonu kritik öneme sahiptir Herhangi bir hizmet sürecinde yaşanacak bir aksama, hizmet zincirinde diğer hizmetlerde de aksamalara sebep olabilecektir. Bu durum hizmet kalitesinde de büyük çapta problemlere yol açacaktır. Aynı zamanda hizmet işletmelerinin emek yoğun yapısı gereği müşteriler ve işletmenin çalışanları yoğun etkileşim içerisinde bulunmaktadırlar. İletişimin bu denli yoğun olması da hizmet hatalarının oluşmasında ve hizmet kalitesinde problemler yaşanmasında tetikleyici bir neden olmaktadır. Diğer yandan hizmetlerin yapısı gereği önceden önlemlerin alınamaması ve bu nedenle kontrol edilemeyen koşulların oluşması da hizmet hatalarına sebebiyet vermektedir.

Turizm sektöründe yaşanılan hizmet hatalarının sınıflandırılmasına yönelik çalışmalar temel itibariyle Bitner (1990)'in yürüttüğü çalışmaya dayanmaktadır. Bu çalışma özellikle otel, restoran ve hava yolu işletmelerini ele almakta ve bu sektörlerde ortaya çıan hizmet hatalarını incelemektedir. Bitner, Booms ve Tetreault (1990)'ın çalışmasına ek olarak Baker, Meyer ve Johnson (2008) da hizmet hatalarının oluşmasına neden olan faktörleri; "(1) tüketiciye uygun olmayan hizmetler, (2) nedensizce hizmetin yavaş sunumu, (3) tüketicilerin özel ihtiyaçlarına yönelik çalışanların cevaplarının yetersiz kalması, (4) istemsiz ve istekli olarak yapılan çalışanların olumsuz eylemleri vb." şeklinde sınıflandırmaktadır. Bitner, Booms ve Mohr ise 1994 yılında yaptıkları çalışmalarında bu hata türleri içerisine "Problemli Müşteri Davranışları" faktörünü de eklemişlerdir. Problemli müşteri davranışları; sarhoş, uyumsuz, işletme kurallarını ihlal eden ya da sözlü veya fiziksel taciz gibi eylemlerde bulunan müşterilerden kaynaklı hizmet hatalarını temsil etmektedir.

Hoffman vd., (1995) ise tespit ettikleri 14 hizmet hatasını temel olarak 3 başlık altında toplamıştır;

$\checkmark$ Servis Sisteminden Kaynaklanan Hizmet Hataları: Kusurlu ürün, yaşanılan genel temizlik ve hijyen problemleri, sunulan servisin yavaş ve/veya yetersiz olması, tükenmiş yemek, net olmayan işletme politikaları, vb.

$\checkmark$ Müşteri İsteklerinin Yerine Getirilmemesinden Kaynaklanan Hizmet Hataları: Servis edilen ürünlerin isteğe göre pişirilmemesi, müşterinin arzu ve beklentilerine uymayan bir yerde oturtulmasi, vb. 
$\checkmark$ Personel Davranışlarından Kaynaklanan Hatalar: Siparişin hatalı alınması, hesabın yanlış alınması, siparişin unutulması, personel davranışları, vb.

Hizmet işletmelerinde hizmet hatalarının yaşanması kaçınılmaz bir durumdur. Birçok hizmet kolunda olduğu gibi personel ve müşteri iletişiminin oldukça yoğun olduğu turizm işletmelerinde hizmet hatalarının önlenmesi oldukça zordur. Hizmet hataları ortaya çıktı̆̆ında, yaşanılan müşteri memnuniyetsizliğini gidermek ve müşteriyi kaybetmemek için işletmeler bu hataların giderilmesine yönelik uygun stratejiler geliştirmek durumundadır.

\section{Hizmet Telafisi ve Telafi Stratejileri}

Hizmet telafisi, hizmet temini sırasında müşterinin beklentilerinin karşılanmaması durumunda oluşan müşteri memnuniyetsizliğinin giderilmesi için işletmenin yaptığ faaliyetlerdir. Bu faaliyetler psikolojik telafi stratejilerinin ve somut çabaların bir bütünüdür. Hizmet telafisi kavramı ilk olarak Bell ve Zemke (1987) tarafından ortaya atılmıştır. Bell ve Zemke'ye (1987) göre hizmet telafisi, müşterilerin beklentilerinin ve isteklerinin belirlenmesi ve karşılanması için yürütülen faaliyetlerin bir bölümüdür. Bu anlamda hizmet telafisi "doğru olanı ikinci kez yapmak" ya da "ilk izlenimi sağlamak için ikinci bir şans" olarak ifade edilmektedir (Cengiz vd., 2015: 88).

Tablo 1. Hizmet Telafi Yöntemleri

\begin{tabular}{|l|l|}
\hline \multicolumn{1}{|c|}{ İlgili Çalışma } & \multicolumn{1}{|c|}{ Hizmet Telafi Yöntemleri } \\
\hline $\begin{array}{l}\text { Bitner vd., 1990; Hart vd., 1990; Kelley vd., } \\
\text { 1993; Hoffman vd., 1995; Tax vd., 1998; Miller } \\
\text { vd., 2000) }\end{array}$ & $\begin{array}{l}\text { Yerine koyma, özür dileme, sürat (dakiklik), } \\
\text { empati, çaba, kolaylaştırma ve onarım (telafi). }\end{array}$ \\
\hline Hoffman ve Kelly; 2000 & $\begin{array}{l}\text { Hatanın kabulü, problemi çözmeyi } \\
\text { önemseyen tavır, özür, tazminat önerisi ve bu } \\
\text { süreçte nazik ve sayglı olma. }\end{array}$ \\
\hline Levesque ve McDougall; 2000 & $\begin{array}{l}\text { Özür (problemi kabul etme); yardım } \\
\text { problemi giderme); tazminat (problemin } \\
\text { masrafları ödeme). }\end{array}$ \\
\hline Davidow; 2003 & $\begin{array}{l}\text { Dakiklik kürat); } \\
\text { düzeltme(telafi-onarım); özür; güvenirlik ve } \\
\text { nezaket. }\end{array}$ \\
\hline $\begin{array}{l}\text { Matilla ve Cranage; 2005 ve Boshoff ve } \\
\text { Staude; 2003 }\end{array}$ & $\begin{array}{l}\text { Geciktirmeden hatayı telafi etme, müşterilere } \\
\text { alternatif seçenekler sunma, hizmet hatası için } \\
\text { özür dileme, indirim yapma veya hediye çeki } \\
\text { sunma, geri bildirim sağlama ve açılama } \\
\text { yapma. }\end{array}$ \\
\hline Forbes vd.; 2005 & $\begin{array}{l}\text { İndirim, düzeltme, pozitif düzeltme, } \\
\text { yenileme, özür, iade (parayı geri ödeme), } \\
\text { mağaza kredisi, yetersiz düzeltme, hiçbir şey } \\
\text { yapmama (tepkisiz kalma). }\end{array}$ \\
\hline
\end{tabular}

Kaynak: Cengiz, vd., 2015: 89 çalışmasından yararlanılarak oluşturulmuştur. 
Literatürde yapılan birçok çalışma etkili bir şekilde uygulanan hizmet telafisi yöntemlerinin, hiç hizmet hatasının deneyimlenmediği durumlara kıyasla daha yüksek müşteri memnuniyeti sağlayacağını öne sürmektedir (Özdemir ve Avcı, 2019; Kambur, 2018; Keiningham vd., 2014; Çalışkan, 2013; Mattila, 1999; Tax vd., 1998; Smith ve Bolton, 1998; Eccles ve Durand, 1998; Spreng vd., 1995; Hart vd., 1990). Etkili bir şekilde uygulanacak hizmet telafisi yöntemleri ile işletmeler bir yandan müşteri memnuniyetsizliğine neden olan şikâyetleri çözüme kavuştururken, diğer yandan da müşteri ve işletme arasında geliştirilecek etkili iletişim ile müşterilerde güven ve sadakat oluşturabilmektedir. Aynı zamanda uygulanacak hizmet telafisi yöntemi işletmeye saygınlık kazandırmakta ve işletmenin müşterinin gözündeki imajı önemli ölçüde olumlu etkilenmektedir. Böylece yaşanılan dezavantajlı durum bir avantaja dönüştürülebilmektedir.

Diğer yandan, etkili ve doğru bir hizmet telafisi stratejisinin belirlenmesi oldukça zor bir faaliyettir (Bitner vd., 1994; Zeithaml vd., 1990). Birçok araştırmada ortaya konulan hizmet telafi yöntemleri Tablo 1'de özetlenmektedir.

\section{Hizmet Telafisi ile Müşteri Memnuniyeti İlişkisi}

Hizmet telafisi, hizmet temin sürecinde hizmet hatası ile karşılaşmış ve memnuniyetsiz olan bir müşterinin işletmenin hizmetlerine yönelik kalite algısını olumlu ya da olumsuz yönde etkileyebilmektedir. Uygulanan hizmet telafisi yönteminin başarılı kabul edilebilmesi için müşterinin yaşadığ 1 olumsuz deneyim sonucunda oluşan memnuniyetsizliğinin ortadan kalkması gerekmektedir. Bunun belirleyicisi ise; müşterinin çevresine olumlu tavsiyelerde bulunması, işletmeye yeniden gelmesi ve yeniden satın alma niyetinde olması şeklinde sıralanan olumlu çıtılardır (Kim vd., 2010; Aktaran: Çalışkan, 2013:69).

Etkin bir şekilde uygulanan hizmet telafisi yöntemleri ile yaşanılan olumsuz algılar kurulan etkin iletişim ile olumluya dönüştürülebilmekte, dezavantajlı olan bu durum avantaja dönüştürülebilmektedir. Birçok çalışmanın da ortaya koyduğu üzere, hizmet telafisi sürecini olumlu olarak deneyimleyen bir müşteri, bu süreci hiç deneyimlemeyen bir müşteriye göre daha yüksek bir memnuniyet düzeyine sahip olmakta ve bu müşteri tarafından algılanan hizmet kalitesi hizmet telafisi deneyimini yaşamayan müşteriden daha yüksek olabilmektedir. Bu durum "hizmet telafi paradoksu" olarak açıklanmaktadır (Fierro vd., 2013; Zeithaml ve Bitner, 2003; Mattila, 1999; Ok vd., 2006; Kim vd., 2010; Maxham ve Netemayer, 2002; Aktaran: Çalışkan, 2013:70).

Hizmet telafisi deneyimi yaşayan müşterilerin bu deneyimi yaşamayan müşterilerden daha yüksek memnuniyet düzeyine sahip olmaları yani hizmet telafi paradoksu, müşteri ile işletme arasındaki iletişimin yoğunlaşması ile açıklanabilir. Günümüzde, tüm pazarlama stratejilerinde artık ürün, ambalaj, dağıtım, fiyat gibi unsurların iletişim boyutları bütünleşik pazarlama iletişimi kapsamında ele alınmaktadır. Dolayısıyla, hizmet telafisi uygulamaları ile işletme ve müşteri arasında arzu edilen iletişim ve etkileşim süreci doğal olarak gelişmektedir. Doğrudan müşteri ile iletişim kurulması ve yaşanılan olumsuzluğun giderilebilmesi için müşterinin ihtiyaç duyduğu hizmetlerin doğru bir şekilde belirlenip kişiye özel olarak sunulması, hatta hizmet hatasının oluşturduğu negatif ortamın ortadan kaldırılması ve yaşanılan dezavantajlı durumun bir avantaja dönüştürülmesi için müşteriye standart hizmetlerin ötesinde ayrıcalıklı bir takım hizmetlerin sunulması, müşterilerin hiç hizmet hatası deneyimlemedikleri durumlarla kıyaslandığında daha yüksek memnuniyet düzeyine sahip olmalarının temel nedenidir.

Hizmet telafi yöntemlerinin yanlış seçilmesi, etkin bir şekilde uygulanmaması ya da hiçbir telafi yönteminin uygulanmaması ise; müşteri memnuniyetsizliği, hatanın tekrarlanmasına bağlı olarak diğer tüketicilere işletme hakkında olumsuz bilgilendirme yapma, herhangi bir tepki 
vermeme ve işletmeye bir daha gelmeme, üçüncü kişilere başvurma ve şikâyette bulunma gibi olumsuz çıktılara sebep olmaktadır (Kim vd., 2010; Aktaran: Çalışkan, 2013:69).

Yaşanılan hizmet hatası sonucunda işletmenin telafi etmek için hiçbir şey yapmaması ya da müşteriye yanlış yanıt vermesi, müşteri memnuniyetsizliğini pekiştirmekte ve müşteri bu durumda ikinci defa memnuniyetsizlik yaşamakta ve işletme hakkında olumsuz değerlendirmeler yapmaktadır. Bu durum literatürde "çifte sapma" olarak tanımlanmaktadır (Hart vd.,1990; Bitner vd., 1990; Aktaran: Çalışkan, 2013:70).

Özellikle internetin yaygın bir şekilde kullanılmaya başlanması ile sosyal medya, müşterilerin deneyimledikleri mal ve hizmetler hakkında tecrübelerini ve düşüncelerini rahatlikla paylaştıkları bir platform haline gelmiştir. Ağızdan ağıza pazarlamanın etkinliği, sosyal medya üzerinde iletişimin kolay ve hızlı olmasıyla daha da artmıştır. Bu ortamda, yaşanılan hizmet hatalarının yarattığı memnuniyetsizliğin giderilmemesi, işletmenin doğru olmayan yaklaşımlarda bulunması ya da tepkisizliği müşterilerin memnuniyetsizliğini pekiştirmekte ve hatta yaşanılan sorunla ilgili üçüncü kişilere ya da yasal yollara başvurmaya kadar tepkilerini arttırmakta, tüm bu yaşanılanların sosyal medya üzerinden paylaşılması ise potansiyel ve mevcut müşterilerin kaybedilmesine, işletme imajının zedelenmesine ve telafisi daha zor değer kayıplarına yol açabilmektedir. Çifte sapma olarak nitelendirilen bu olumsuz durumun yaşanmaması için, hizmet telafi paradoksunda da vurgulandığı üzere hizmet hatası neticesinde memnuniyetsiz olmuş müşterinin bu durumdan çıkarılıp işletme hakkında yeniden olumlu düşünmeye yönlendirecek etkili iletişim yollarının geliştirilmesi gerekmektedir.

\section{UYGULAMA}

\section{Çalışmanın Amacı, Kapsamı ve Örneklemi}

$\mathrm{Bu}$ çalışmanın amacı, yarattığı katma değer büyüklüğü dikkate alındığında diğer hizmet sektörleri arasında ön plana çıkmakta olan hizmet sektöründe faaliyet gösteren turizm işletmelerinde tüketicilerin deneyimledikleri hizmet hatalarının incelenmesi, bu hizmet hatalarının yaşanma sıklı̆̆ının, gerçekleşme oranının, türünün ve hataların kaynağının belirlenmesi, tüketicilerin hizmet hataları karşısında gösterdikleri tepkilerin ölçülmesi, işletmelerin uyguladıkları telafi yöntemlerinin ve bu yöntemlerin etkinliğinin belirlenmesidir. Aynı zamanda hizmet telafisi uygulaması sonrasında müşteri memnuniyetinde ve algisında meydana gelen değişimler ve hizmet hatalarının tüketici tercihleri üzerindeki etkisi ortaya konulmaya çalışılmıştır.

Bu amaçla Temmuz-Ağustos 2019 döneminde internet ortamında 394 tüketiciye anket uygulanmıştır. Çalışmanın örneklemi, amaçsal /yargısal örnekleme yöntemi ile belirlenmiş ve daha önce en az bir defa turizm işletmelerinde hizmet hatası ile karşılaşmış olmaları şartı aranmıştır. Bu şartı karşılamayan 7 katılımcı elenmiş ve araştırmaya dâhil edilmemiş, toplamda 387 anket değerlendirmeye alınmıştır.

\section{Veri Toplama Yöntemi}

Bu çalışmada veriler anket yöntemi kullanılarak elde edilmiştir. Anket formu daha önce turizm işletmelerinde hizmet hatası ile karşılaşmış olan tüketicilere uygulanmıştır. Anket formu dört bölümden oluşmaktadır. İlk bölümde, katılımcıların demografik özelliklerini belirlemeye yönelik sorular, ikinci bölümde hizmet hatalarını belirlemeye yönelik sorular, üçüncü bölümde hizmet 
hatalarını telafi yöntemlerine ilişkin sorular ve son bölümde ise müşteri memnuniyetini belirlemeye yönelik sorular yer almaktadır.

Kullanılan anket formunda hata türlerini belirlemeye yönelik ifadeler Bitner, Booms ve Tetreault (1990) tarafından ortaya konulan ve sonrasında Bitner, Booms ve Mohr (1994) tarafından geliştirilen hizmet hata türlerinden yararlanılarak oluşturulmuştur. Hizmet telafisi türlerinin belirlenmesine yönelik ifadeler için ise Hoffman vd.'nin (1995) ve Mostafa vd.'nin (2014) çalışmalarından yararlanılmıştır. Müşteri memnuniyetinin ölçülmesi, yaşanılan hizmet hatasının kaynağının belirlenmesi ve hata sonrasında gösterilen tepkilerin ölçülmesi amacıyla kullanılan ifadeler Olcay ve Özekinci'nin (2015) ve Phau ve Ferguson'un (2013) çalışmalarından faydalanılarak oluşturulmuştur. Çalışmaya uyarlanabilmesi açısından hizmet hata türlerine ait ifadeler üzerinde yapılan düzeltmeler de Olcay ve Özekinci'nin (2015) çalışmasından alınmıştır. Buna göre; Hoffman vd.'nin (1995) çalışmasında kullanılan "tükenmiş yemek" ifadesi yerine "porsiyon miktarının yetersizliği" ifadesi kullanılmıştır. Bitner vd.'nin (1994) çalışmasında yer alan "uyumsuz müşteri" ve "sarhoş müşteri" ifadeleri yerine "diğer müşterilerin rahatsız edici tüketim davranışları" ve "diğer müşterilerin aşırı sesli konuşması" hizmet hatası türleri olarak alınmıştır. Telafi yöntemlerine ait ifadelerde Hoffman vd.'nin (1995) çalışmasında yer alan "düzeltme" ifadesi yerine "özür dilendi ve hata hemen giderildi" ifadesi kullanılmıştır. Benzer şekilde "yönetimin müdahalesi" ifadesi yerine "şikâyet bir üst makama yönlendirildi" ve "kupon" yerine "sadece açıklama yapıldı" ifadesi telafi yöntemi olarak ele alınmıştır.

Hizmet hatası ve telafi yöntemlerine ait ifadeler kapalı uçlu ve çok seçenekli olarak sorulmuş, müşteri memnuniyetine ait ifadeler ise 5'li Likert ölçeği ile oluşturulmuştur. Buna göre; 1: Kesinlikle Katılmiyorum, 2: Katılmiyorum, 3: Ne Katıliyorum Ne De Katılmiyorum, 4: Katılıyorum, 5: Kesinlikle Katılıyorum şeklinde kodlanmıştır.

\section{Araştırmanın Güvenilirliği ve Faktör Analizi}

Araştırmada kullanılan ölçeklerin Cronbach's Alfa Katsayısına bakıldığında; "hizmet hataları" ölçeğinin 0,909; "hizmet telafisi yöntemleri" ölçeğinin 0,886 ve "müşteri memnuniyeti" ölçeğinin 0,825'dir ve bu değerlere göre ölçeklerin güvenilirlik dereceleri yüksektir. 18 maddeden oluşan "hizmet hataları" ölçeğinin KMO (Kaiser-Meyer-Olkin) değeri 0,887; Bartlett'in küresellik testi değeri 6912,554 ve p=0,000'dır. 17 maddeden oluşan "hizmet telafisi yöntemleri" ölçeğinin KMO değeri 0,896; Bartlett'in küresellik testi değeri 965,712 ve $p=0,000$ 'dır. 6 maddeden oluşan "müşteri memnuniyeti" ölçeği için KMO 0,701; Bartlett'in küresellik testi değeri 376,692 ve $\mathrm{p}=0,000$ 'dır. Bu verilere göre gerçekleştirilen faktör analizi sonucu "hizmet hataları" ölçeğinden 3 boyut oluşmuştur ve bu boyutların toplam varyansa katkısı \%74,098'dir. "Hizmet telafisi yöntemleri" ölçeğine ait dört boyut meydana gelmiştir ve bu boyutların toplam varyansa katkısı \%77,496'dır. "Müş̧eri memnuniyeti" ölçeği tek bir boyut altında toplanmış ve toplam varyansa \%65,297 katkı sağlamıştır. "Hizmet hataları" ölçeğine ait boyutlara "çalışan hataları", "diğer müşterilerin hataları" ve "işletme yönetiminin hataları"; "hizmet telafisi yöntemleri" ölçeğinin boyutlarına "özür dileme", "telafi etme", "açıklama yapma" ve "sorun giderme" adlarl; "müşteri memnuniyeti" ölçeğine ait boyuta da yine "müşteri memnuniyeti" adı verilmiştir. Boyutların adlandırmaları yapılırken literatürdeki adları dikkate alınmıştır. Tablo 2 ile boyutlara ilişkin bilgiler gösterilmektedir. 
Tablo 2: Araştırmada kullanılan boyutlar

\begin{tabular}{|l|l|}
\hline \multirow{4}{*}{ Ölçek } & Faktörü \\
\hline \multirow{3}{*}{ Hizmet Hataları } & Çalışan Hataları \\
\cline { 2 - 2 } & Diğer Müşterilerin Hataları \\
\cline { 2 - 2 } & İşletme Yönetiminin Hataları \\
\hline \multirow{3}{*}{ Hizmet Telafisi Yöntemleri } & Özür Dileme \\
\cline { 2 - 2 } & Telafi Etme \\
\cline { 2 - 2 } & Açıklama Yapma \\
\cline { 2 - 2 } & Sorun Giderme \\
\hline \multirow{2}{*}{ Müşteri Memnuniyeti } & Müşteri Memnuniyeti \\
\hline
\end{tabular}

\section{Araştırmanın Hipotezleri}

Araştırmanın amacı turizm işletmelerinde hizmet hataları ve bu hataları onarabilmek için gerçekleştirilen çabaların (hizmet telafisi yöntemlerinin) müşteri memnuniyeti üzerindeki etkisini görebilmektir. Buradan yola çıarak araştırmanın temel amacının Şekil 1'deki gibi olduğu belirtilebilir. Şekil 1'de de görüldügü gibi turizm işletmeleri sundukları hizmetlerle ilgili hatalar yapabilmektedir ve bunun sonucu bu hataları telafi edici uygulamalar gerçekleştirmektedir. İşte bu iki durumun müşteri memnuniyetini ne derece etkilediği anlaşılmaya çalışılmaktadır.

Şekil 1: Araştırmanın Temel Amacı

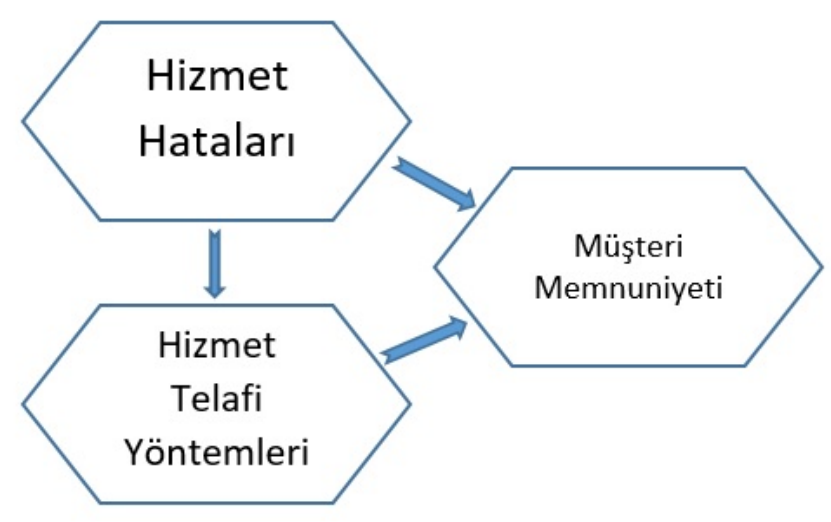

Araştırma ölçeklerine uygulanan faktör analizi sonucu "hizmet hataları" ölçeği için üç ve "hizmet telafi yöntemleri" ölçeği için de dört boyut ortaya çıkmış ve böylece araştırma için yedi bağımsız değişken geliştirilmiştir. Söz konusu bu yedi bağımsız değişkenin "müşteri memnuniyeti" bağımlı değişkeni üzerindeki etkisi sınanmaktadır. Araştırmanın amacı esasında "hizmet hataları" ve "hizmet telafi yöntemleri" işlemlerinin "müşteri memnuniyeti" üzerindeki etkisini ortaya koyabilmek olduğu için, hipotezler de araştırmanın etkileyen ölçeklerine ait boyutların etkilenen ölçeğe ait boyut üzerindeki etkisine yönelik olarak oluşturulmuştur. Bu doğrultuda araştırmanın hipotezleri şunlardır; 
H1a: Çalışan hatalarının müşteri memnuniyeti üzerinde etkisi bulunmaktadır,

H1b: Diğer müşterilerin hatalarının müşteri memnuniyeti üzerinde etkisi bulunmaktadır,

H1c: İşletme yönetiminin hatalarının müşteri memnuniyeti üzerinde etkisi bulunmaktadır,

H2a: İşletmenin özür dileme çabalarının müşteri memnuniyeti üzerinde etkisi bulunmaktadır,

$\mathrm{H} 2 \mathrm{~b}$ : İşletmenin telafi etme çabalarının müşteri memnuniyeti üzerinde etkisi bulunmaktadır,

H2c: İşletmenin açıklama yapma çabalarının müşteri memnuniyeti üzerinde etkisi bulunmaktadır,

H2d: İşletmenin sorun giderme çabalarının müşteri memnuniyeti üzerinde etkisi bulunmaktadır.

\section{BULGULAR}

Çalışmanın bu kısmında; katılımcıların demografik özellikleri, örnekleme sunulan diğer tanımlayıcı soruların yanıtları ve oluşturulan hipotezleri sınamak için regresyon analizi sonuçları sunulmuştur.

\section{Demografik Bulgular}

Araştırma örnekleminin \%47'si kadın ve \%53'ü erkektir. Bunun yanı sıra \%51,4'ü evli; \%48,6's1 bekar; \%28,4'ü 25-34 yaş aralığında; \%28'i lise eğitim seviyesinde; \%29,1'i memur ve \%30,7'si 4001-6000 TL arasi gelire sahiptir.

Tablo 3: Örneklemin Demografik Özellikleri

\begin{tabular}{|c|c|c|c|}
\hline Değişken & Gruplar & Frekans & $\%$ \\
\hline \multirow{2}{*}{ Cinsiyet } & Kadın & 182 & 47,0 \\
\hline & Erkek & 205 & 53,0 \\
\hline \multirow{2}{*}{ Medeni Hal } & Bekâr & 199 & 51,4 \\
\hline & Evli & 188 & 48,6 \\
\hline \multirow{5}{*}{ Yaş Aralığı } & $18-24$ & 79 & 20,4 \\
\hline & $25-34$ & 110 & 28,4 \\
\hline & $35-44$ & 90 & 23,4 \\
\hline & $45-54$ & 57 & 14,7 \\
\hline & +55 & 51 & 13,1 \\
\hline \multirow{6}{*}{ Eğitim Durumu } & İlkokul & 4 & 1,0 \\
\hline & Ortaokul ve Dengi & 59 & 15,2 \\
\hline & Lise & 108 & 28,0 \\
\hline & Önlisans & 98 & 25,4 \\
\hline & Lisans & 79 & 20,4 \\
\hline & Lisansüstü & 39 & 10,0 \\
\hline \multirow{6}{*}{ Meslek } & İşçi-Çiftçi & 18 & 4,7 \\
\hline & Memur & 112 & 29,1 \\
\hline & Öğrenci & 42 & 11,1 \\
\hline & Ev Kadını & 4 & 1,0 \\
\hline & Yönetici & 48 & 12,3 \\
\hline & Uzman (Dr., Avukat, Mühendis Gibi) & 91 & 23,4 \\
\hline
\end{tabular}




\begin{tabular}{|l|l|c|c|}
\hline \multirow{5}{*}{} & İssiz & 23 & 5,9 \\
\cline { 2 - 4 } & Diğer & 49 & 12,5 \\
\hline \multirow{5}{*}{ Hane Gelir Durumu (TL) } & -2020 & 61 &, 8 \\
\cline { 2 - 4 } & 2020 & 48 & 2,4 \\
\cline { 2 - 4 } & $2021-4000$ & 71 & 23,3 \\
\cline { 2 - 4 } & $4001-6000$ & 80 & 30,7 \\
\cline { 2 - 4 } & $6001-8000$ & 56 & 24,5 \\
\cline { 2 - 4 } & +8000 & 71 & 18,3 \\
\hline
\end{tabular}

\section{Araştırmanın Diğer Tanımlayıcı Bulguları}

Diğer tanımlayıcı bulgular kısmında örnekleme yöneltilen "turizm işletmelerinde ne sıklıkla hizmet hatası ile karşılaştığı", "katılımcıların turizm işletmelerinde yaşamış olduğu hizmet hatasının kaynağı", "turizm işletmelerinde yaşamış olduğu hizmet hatası sonrasında nasıl bir tepki gösterdiği", "turizm işletmelerinde ne tür hizmet hataları ile karşılaştıkları", "turizm işletmelerinde yaşamış oldukları hizmet hatasının nasıl telafi edildiği", "yaşadıkları hizmet hatası sonucunda uygulanan telafi yönteminden memnun olup olmadıkları", "yaşadıkları hizmet hatası için uygulanan telafi yöntemi sonrasında o turizm işletmesine karşı tutumlarında bir değişiklik olup olmadığı", "hizmet hatasını telafi eden turizm işletmesine güven duyulup duyulmadığı", "hizmet hatasını telafi eden turizm işletmesinin tekrar tercih edilip edilmeyeceği" sorularının yanıtları sunulmaktadır.

Katılımcların \%48'i nadiren ve \%25,'i bazen hizmet hatası ile karşılaşırken, 7 katılımcı $(\% 1,8)$ hiç hizmet hatası ile karşılaşmadığını belirtmiş ve araştırmaya dâhil edilmemiştir. Tablo 4'te dikkat çeken bulgular; \%23,6 oranında hataların daha çok işletme sahibinden/yönetiminden ve \%21,8 oranında diğer müşterilerden kaynaklı olduğu; \%31,8 oranında bu hataların akraba/arkadaş çevresinde konuşularak dile getirildiği (yani olumsuz ağızdan ağıza pazarlama yapıldığı); \%8,3 oranında yiyecek alternatiflerin yetersizliğinden memnun kalmadıkları; bu hataların \%17,4 oranında işletme tarafından özür dilenip, telafi edildiği; ancak \%36 oranında bu telafi çabalarının yetersiz olduğu ve bundan dolayı da $\% 45,5$ oranında işletmeye karşı olan olumsuz tutumlarında bir değişiklik olmadığı; \%61,8'inin işletmeye olan güveninin devam etmeyeceği ve \%60,9'unun bu işletmeyi tekrar tercih etmeyeceği şeklindedir.

Tablo 4: Araştırmanın Diğer Tanımlayıcı Bulguları

\begin{tabular}{|l|l|c|c|}
\hline Değişken & Grup & Frekans & $\mathbf{\%}$ \\
\hline \multirow{4}{*}{$\begin{array}{l}\text { Turizm işletmelerinde ne } \\
\text { sıklıkla hizmet hatası ile } \\
\text { karşılaştı̆̆ }\end{array}$} & Her Zaman & 61 & 15,5 \\
\cline { 2 - 4 } & Sıklıkla & 38 & 9,6 \\
\cline { 2 - 4 } & Bazen & 99 & $\mathbf{2 5 , 1}$ \\
\cline { 2 - 4 } & Nadiren & 189 & $\mathbf{4 8 , 0}$ \\
\cline { 2 - 4 } & Hiçbir Zaman & $\mathbf{7}$ & 1,8 \\
\hline \multirow{3}{*}{$\begin{array}{l}\text { Katıllımclların turizm } \\
\text { işletmelerinde yaşamış }\end{array}$} & Servis Personeli & 81 & 20,9 \\
\cline { 2 - 4 } & Mutfak Personeli & 70 & 18,2 \\
\cline { 2 - 4 } & İşletme Sahibi/yönetimi & 91 & $\mathbf{2 3 , 6}$ \\
\hline
\end{tabular}




\begin{tabular}{|c|c|c|c|}
\hline \multirow{3}{*}{$\begin{array}{l}\text { olduğu hizmet hatasının } \\
\text { kaynağ1 }\end{array}$} & Müşterinin Kendisi & 25 & 6,4 \\
\hline & Diğer Müşteri/Müşteriler & 84 & 21,8 \\
\hline & Diğer & 36 & 9,1 \\
\hline \multirow{7}{*}{$\begin{array}{l}\text { Turizm işletmelerinde } \\
\text { yaşamış olduğu hizmet } \\
\text { hatası sonrasında nasıl bir } \\
\text { tepki gösterdiği }\end{array}$} & İşletme Yetkilisine Şikâyette Bulunma & 85 & 21,8 \\
\hline & Servis Personeline Şikâyette Bulunma & 28 & 7,3 \\
\hline & Sosyal Medyada Paylaşma & 21 & 5,5 \\
\hline & Yasal Yollara Başvurma & 53 & 13,6 \\
\hline & Arkadaşlara/Akrabalara Bahsetme & 123 & 31,8 \\
\hline & Hiçbir Şey Yapmama & 32 & 8,2 \\
\hline & Diğer & 45 & 11,8 \\
\hline \multirow{20}{*}{$\begin{array}{l}\text { Turizm işletmelerinde ne } \\
\text { tür hizmet hataları ile } \\
\text { karşılaşıkları }\end{array}$} & İşletmenin Vaat Edildiği Gibi Çıkmaması & 14 & 3,6 \\
\hline & Hizmetin Yavaş ve/veya Yetersiz Olması & 7 & 1,8 \\
\hline & Temizlik ve/veya Hijyen Problemleri & 21 & 5,5 \\
\hline & Odanın Fiziksel Koşullarının Yetersizliği & 17 & 4,5 \\
\hline & Net Olmayan İşletme Politikaları & 21 & 5,5 \\
\hline & İptal / İade Politikalarının Yetersizliği & 11 & 2,7 \\
\hline & Yiyecek Alternatiflerin Yetersizliği & 32 & 8,3 \\
\hline & $\begin{array}{l}\text { Eğlence Alternatiflerin Yetersizliği (Animasyon, } \\
\text { Gece Kulübü }\end{array}$ & 18 & 4,5 \\
\hline & Çocuklara Yönelik Hizmetlerin Yetersizliği & 11 & 2,7 \\
\hline & Beklentilerin Doğru Anlaşılmaması & 21 & 5,5 \\
\hline & $\begin{array}{l}\text { Müşterinin İstek ve Beklentisine Uymayan } \\
\text { Seçeneklerin Sunum }\end{array}$ & 14 & 3,6 \\
\hline & $\begin{array}{l}\text { Personelin Kaba Olması veya Yeteri Kadar İlgili } \\
\text { Olmaması }\end{array}$ & 14 & 3,6 \\
\hline & Hatalı Rezervasyon Alınması & 14 & 3,6 \\
\hline & Rezervasyonun Unutulması & 16 & 4,5 \\
\hline & Ödemenin Yanlış Alınması & 11 & 2,7 \\
\hline & $\begin{array}{l}\text { Diğer Müşterilerin Rahatsız Edici Tüketim } \\
\text { Davranışları }\end{array}$ & 21 & 5,5 \\
\hline & Diğer Müşterilerin Aşırı Gürültülü Olmaları & 39 & 10,0 \\
\hline & Diğer Müşterilerin Sözlü Ya Da Fiziksel Tacizi & 7 & 1,8 \\
\hline & $\begin{array}{l}\text { Diğer Müşterilerin İşletme Politikalarını } \\
\text { Çiğnemesi }\end{array}$ & 14 & 3,6 \\
\hline & Diğer & 64 & 16,5 \\
\hline \multirow{5}{*}{$\begin{array}{l}\text { Turizm işletmelerinde } \\
\text { yaşamış oldukları hizmet } \\
\text { hatasının nasıl telafi } \\
\text { edildiği }\end{array}$} & Hiç Hesap Alınmadı & 7 & 1,8 \\
\hline & İndirim Yapıldı & 11 & 2,7 \\
\hline & Şikâyet Bir Üst Makama Yönlendirildi & 21 & 5,5 \\
\hline & Özür Dilendi ve Hata Hemen Giderildi & 68 & 17,4 \\
\hline & Odaya Özel Servisler Yapıldı & 14 & 3,6 \\
\hline
\end{tabular}




\begin{tabular}{|c|c|c|c|}
\hline & Ücretli Hizmetlerden Bazıları Hediye Edildi & 25 & 6,4 \\
\hline & Oda Değişikliği Yapıldı & 42 & 10,9 \\
\hline & Sadece Açıklama Yapıldı & 14 & 3,6 \\
\hline & Sadece Özür Dilendi & 56 & 14,5 \\
\hline & Hiçbir Şey Yapılmadı & 60 & 15,5 \\
\hline & Diğer & 69 & 18,1 \\
\hline \multirow{3}{*}{$\begin{array}{l}\text { Yaşadıkları hizmet hatası } \\
\text { sonucunda uygulanan } \\
\text { telafi yönteminden } \\
\text { memnun olup olmadıkları }\end{array}$} & $\begin{array}{l}\text { Genel Olarak Başvurulan Yöntemden Büyük Bir } \\
\text { Keyif Aldım }\end{array}$ & 53 & 13,6 \\
\hline & $\begin{array}{l}\text { Genel Olarak İşletmenin Yöntemi Olması } \\
\text { Gerektiği Gibiydi }\end{array}$ & 187 & 48,2 \\
\hline & Genel Olarak Başvurulan Yöntem Yetersizdi & 147 & 38,2 \\
\hline \multirow{3}{*}{$\begin{array}{l}\text { Yaşadikları hizmet hatası } \\
\text { için uygulanan telafi } \\
\text { sonrasında o turizm } \\
\text { işletmesine karşı } \\
\text { tutumlarında bir } \\
\text { değişiklik olup olmadığı }\end{array}$} & Daha Olumlu Oldu & 113 & 29,1 \\
\hline & Hiçbir Değişiklik Olmadı & 176 & 45,5 \\
\hline & Daha Olumsuz Oldu & 98 & 25,4 \\
\hline \multirow{2}{*}{$\begin{array}{l}\text { Hizmet hatasını telafi } \\
\text { eden turizm işletmesine } \\
\text { güven duyulup } \\
\text { duyulmadığı }\end{array}$} & Hayır & 239 & 61,8 \\
\hline & Evet & 148 & 38,2 \\
\hline \multirow{2}{*}{$\begin{array}{l}\text { Hizmet hatasını telafi } \\
\text { eden turizm işletmesinin } \\
\text { yeniden tercih edilip } \\
\text { edilmeyeceği }\end{array}$} & Hayır & 236 & 60,9 \\
\hline & Evet & 151 & 39,1 \\
\hline
\end{tabular}

\section{Regresyon Analizi}

Çoklu regresyon analizi ile "hizmet hataları" ölçeğine ait olan "çalışan hataları", "diğer müşterilerin hataları", "işletme yönetiminin hataları" ile "hizmet telafisi yöntemleri" ölçeğine ait "özür dileme", "telafi etme", "açıklama yapma" ve "sorun giderme" boyutlarının "müşteri memnuniyeti" boyutu üzerindeki etkisi belirlenmeye çalışılmaktadır.

Tablo 5'de görüldüğ ü gibi tüm modellerde $\mathrm{p}<, 05$ ' dir. Bu sonuca göre oluşturulan tüm modellerde bağımsız değişkenin bağımlı değişken üzerinde etkisi bulunmaktadır. Bir başka deyişle ortaya çıkn tüm boyutların "müşteri memnuniyeti" üzerinde etkisi bulunmaktadır. Buradan yola çıkarak araştırmada kurulan $\mathrm{H} 1 \mathrm{a}, \mathrm{H} 1 \mathrm{~b}, \mathrm{H} 1 \mathrm{c}, \mathrm{H} 2 \mathrm{a}, \mathrm{H} 2 \mathrm{~b}, \mathrm{H} 2 \mathrm{c}$ ve $\mathrm{H} 2 \mathrm{~d}$ hipotezlerinin tümü kabul edilebilmektedir. Hizmet hataları ile müşteri memnuniyeti arasındaki ilişkisi ters yöndedir. Bir başka ifade ile hizmet hataları müşteri memnuniyetini olumsuz yönde etkilemekte, bir başka anlatımla hizmet hataları müşteri memnuniyetini azaltmaktadır. İşletme yönetiminin hataları $(\beta=-, 448)$ en fazla etkiye sahiptir. İşletme yönetiminin hatalarına karşı tüketicilerin 1 birimlik tutum değişikliği memnuniyet düzeylerinde -,448 birimlik bir değişikliğe yol açmaktadır. Bir başka deyişle müşterilerin işletme yönetiminden kaynaklı hizmet hataları konusundaki düşüncelerinde bir birimlik olumsuz tutum artışı, memnuniyet düzeylerini 0,448 birim düşürmektedir. Bunu sırasıyla çalışanların hataları $(\beta=-, 446)$ ve diğer müşterilerin hataları $(\beta=-$ ,289) takip etmektedir. Bu hataları düzeltme çabalarının müşteri memnuniyeti üzerindeki 
etkisine bakıldığındaysa en fazla etkiye $(\beta=, 336)$ telafi etme çabaları sahiptir (müşterilerin; işletmenin hatlarını telafi etme çabalarına karşı bakış açılarındaki 1 birimlik olumlu yöndeki bir artış, müşterilerin memnuniyet seviyelerini 0,336 birim artırmaktadır). Bir başka anlatımla bir hata karşısında müşterilerden özür dileme, açıklama yapma, sorunu giderme yönünde davranışların yanı sıra hatayı telafi edici başka uygulamaların (odaya yemek gönderme, indirim yapma, ücretsiz akşam yemeği, armağanlar sunma, hizmetin ücrete tabi olanaklarından ücretsiz faydalanma gibi) müşterilerin memnuniyet derecesini daha fazla etkilediği sonucu ortaya çıkmaktadır. Buna karşılık en az etkiye ise yalnızca özür dileme uygulamaları sahiptir $(\beta=, 264)$.

Tablo 5: Çoklu Regresyon Analizi Sonuçları

\begin{tabular}{|c|c|c|c|c|c|c|c|}
\hline Model & Ölçek & $\begin{array}{l}\text { Bağımsız } \\
\text { Değişken }\end{array}$ & $\begin{array}{c}\text { Bağımlı } \\
\text { Değişken }\end{array}$ & $\mathbf{R}^{2}$ & $\begin{array}{c}\text { P Değeri } \\
\left(\mathbf{R}^{2)}\right.\end{array}$ & $\beta$ & $\begin{array}{c}\text { P Değeri } \\
(\beta)\end{array}$ \\
\hline 1 & \multirow{3}{*}{$\begin{array}{l}\text { Hizmet } \\
\text { Hataları }\end{array}$} & $\begin{array}{l}\text { Çalışan } \\
\text { Hataları }\end{array}$ & $\begin{array}{c}\text { Müşteri } \\
\text { Memnuniyeti }\end{array}$ & 685 & ,000 &,- 446 & ,000 \\
\hline 2 & & $\begin{array}{c}\text { Diğer } \\
\text { Müşterilerin } \\
\text { Hataları } \\
\end{array}$ & $\begin{array}{c}\text { Müşteri } \\
\text { Memnuniyeti }\end{array}$ & 685 & ,000 &,- 289 & ,002 \\
\hline 3 & & $\begin{array}{c}\text { İşletme } \\
\text { Yönetiminin } \\
\text { Hataları }\end{array}$ & $\begin{array}{c}\text { Müşteri } \\
\text { Memnuniyeti }\end{array}$ & 685 & ,000 &,- 448 & ,000 \\
\hline 4 & \multirow{4}{*}{$\begin{array}{c}\text { Hizmet } \\
\text { Telafisi } \\
\text { Yöntemleri }\end{array}$} & $\begin{array}{l}\text { Özür } \\
\text { Dileme }\end{array}$ & $\begin{array}{c}\text { Müşsteri } \\
\text { Memnuniyeti }\end{array}$ & 877 & ,000 & ,264 & ,001 \\
\hline 5 & & Telafi Etme & $\begin{array}{c}\text { Müşteri } \\
\text { Memnuniyeti }\end{array}$ & ,877 & ,000 & ,336 & ,000 \\
\hline 6 & & $\begin{array}{l}\text { Açılama } \\
\text { Yapma }\end{array}$ & $\begin{array}{c}\text { Müşteri } \\
\text { Memnuniyeti }\end{array}$ & ,877 & ,000 & ,280 & ,001 \\
\hline 7 & & $\begin{array}{c}\text { Sorun } \\
\text { Giderme }\end{array}$ & $\begin{array}{c}\text { Müşteri } \\
\text { Memnuniyeti }\end{array}$ & ,877 & ,000 & ,296 & ,001 \\
\hline
\end{tabular}

Hizmet hataları içerisinde yönetimden kaynaklanan hataların en büyük etkiye neden olması, müşterilerin hizmet noktalarında yaşadıkları olumsuz deneyimlerin temelinde yönetimsel problemlerin olduğuna işaret etmektedir. Net olmayan işletme politikalarından, kontrolü ve denetimi yapılmayan hizmet standartlarına kadar uzanan bir yelpazede yaşanabilecek olan yönetimsel problemler neticesinde müşterilerin yaşadıkları memnuniyetsizlikler göreceli olarak daha yüksek olmaktadır. Çalışanlardan ve diğer müşterilerden kaynaklanan hizmet hatalarının ön sırada yer alması da yönetimin bu konuda önleyici etkin bir strateji uygulamakta yetersiz kaldığını göstermektedir. Aynı zamanda hizmet hatalarının telafisinde sadece özür dilemenin yeterli bir telafi olmadığı, müşterilerin yaşadıkları olumsuzluklar karşısında işletme yönetiminden daha ayrıcalıklı bir hizmet ve yaklaşım beklediklerini ortaya koymaktadır. Bu aşamada önemli olan müşterinin işletme yönetiminin hizmet telafisi konusunda hassasiyetini ve gayretini görebilmesi, telafi etme çabalarını samimi bulmasıdır.

\section{SONUÇ VE ÖNERILER}

Hizmetlerin yapısı gereği, hizmet sektöründe hizmetin sunumu esnasında sıklıkla hizmet hataları yaşanabilmektedir. Hizmet hatalarını önlemek mümkün olmasa da, daha az yaşanmasını 
sağlayacak önlemlerin alınması ya da müşteri memnuniyetinin olumsuz etkilenmemesi için yaşanan hizmet hatalarının telafi edilmesi yönünde uygulamaların yapılması mümkündür.

Hizmet hataları ve telafi yöntemleri ile ilgili literatürde yer alan çalışmalar göstermektedir ki, doğru şekilde uygulanan hizmet telafi yöntemleri müşteri memnuniyetini olumlu yönde etkileyebilmekte, hatta hiç hatanın deneyimlenmediği durumlara kıyasla daha yüksek müşteri memnuniyetinin elde edilmesi söz konusu olabilmektedir.

$\mathrm{Bu}$ çalışmada, turizm işletmelerinde yaşanılan hizmet hatalarının incelenmesi, bu hizmet hatalarının yaşanma sıklığının, gerçekleşme oranının, türünün ve hataların kaynağının belirlenmesi, tüketicilerin hizmet hataları karşısında gösterdikleri tepkilerin ölçülmesi, işletmelerin uyguladıkları telafi yöntemlerinin ve bu yöntemlerin etkinliğinin belirlenmesi amaçlanmıştır. Aynı zamanda hizmet telafisi uygulaması sonrasında müşteri memnuniyetinde ve algısında meydana gelen değişimler ve hizmet hatalarının tüketici tercihleri üzerindeki etkisi ortaya konulmaya çalışılmıştır.

Araştırma bulgularına göre katılımcıların \%48'i nadiren, \%25,1'i bazen, \%15,5'i her zaman ve \%9,6'sı sıklıkla hizmet hatası ile karşılaşırken, \%1,8'i hiçbir zaman hizmet hatası ile karşılaşmadıklarını belirtmiş ve bu \%1,8'lik kısım araştırmaya dâhil edilmemiştir. Hizmet hatalarının bu kadar yaygın karşılaşılıyor olması, rekabetin oldukça yoğun olduğu turizm sektöründe yöneticilerin dikkate almaları gereken bir husustur. Özellikle günümüz bilişim teknolojileri ile iletişim sosyal medya kanalları üzerinden oldukça kolay hale gelmiş ve bilinçlenen yeni bir tüketici profili oluşmuştur. Tüketiciler artık araştırmadan ve işletmeler ile ilgili sosyal medyadaki yorumları okumadan satın alma yapmamaktadır. Web siteleri üzerinden oluşturulan tüketici forumlarında yaşadıkları olumsuz tecrübeleri paylaşan müşteriler, diğerlerinin de kararlarını olumsuz yönde etkilemektedir. Bu nedenle, hizmet sonrası müşterinin memnun şekilde işletmeden ayrılması, uzun vadede işletmenin müşteri sadakati elde edebilmesinin ve ayakta kalabilmesinin öncelikli koşullarındandır.

Turizm işletmelerinde yaşanılan hizmet hatalarının başlıca kaynağı \%23,6'lık bir oranla işletmenin sahibi ya da yöneticisi olarak görülmektedir. Bunu $\% 21,8$ ile diğer müşterilerin sebep olduğu hizmet hataları takip etmektedir. \%20,9 ile servis personeli, \%18,2 ile mutfak personeli, $\% 6,4$ ile müşterinin kendisi ve \%9,1 ile diğer etmenler hizmet hatalarının kaynağı olarak görülmektedir. Burada hataların temelinde yönetimsel sorunların yattığı görülmektedir. Diğer müşterilerden kaynaklanan sorunların da temelinde yönetimsel problemler yatmaktadır. Yeterli ve zamanında önleyici planlamaların yapılmaması ve yönetimin bu konuda yeterli hassasiyeti göstermemesi de hataların yaşanmasında etkendir. Bu konuda işletme politikaların ve sınırlamaların net olması, yönetimin bu konuda taviz vermemesi ve uyarıların önceden anlaşılır şekilde yapılması hataların yaşanma sıklığını azaltacaktır. Diğer yandan servis ve mutfak personeli ile ilgili yaşanılan sorunlar da etkili insan kaynakları yönetimi ve sürekli personel eğitimi ile büyük ölçüde önlenebilecektir. Hatanın kaynağı müşterinin kendisi de olabilmektedir. Bu noktada hassasiyet gösterilmesi gereken husus ise memnuniyetsiz ve hatalı olan müşterinin de uygun yaklaşımlar ile geri kazanılabilmesi ve olumsuz ağızdan ağıza pazarlamanın önüne geçilebilmesidir. Çünkü müşteriler büyük ölçüde deneyimledikleri bütün güzellikleri konaklama yerinde birakacak ve olumsuz deneyimleri beraberinde götüreceklerdir.

Katılımcılara yaşadıkları hizmet hatası sonrasında tepkileri sorulduğunda; \%31,8'i olaydan arkadaşlarına ve/veya akrabalarına bahsettiklerini, \%21,8'i işletme yetkilisine şikâyette bulunduklarını, \%13,6'sı yasal yollara başvurduklarını, \%7,3'ü servis personeline şikâyette bulunduklarını, \%5,5'i durumu sosyal medyada paylaştıklarını ve \%11,8'i ise durumu diğer yöntemlerle çözmeye çalıştıkların belirtmişlerdir. Katılımcıların yalnızca \%8,2'si hiçbir şey yapmadıklarını ifade etmiştir. Katılımcıların \%91,8'inin tepki göstermesi, \%13,6'sının yasal 
yollara başvurması ve \%5,5'inin durumu sosyal medyadan paylaşıyor olması, tüketicilerin yaşanılan hizmet hataları karşısında bilinçlendiğini, haklarını aradıklarını ve bu konuda sosyal medyanın gücünü de kullandıklarını göstermektedir. Böyle bilinçli bir tüketici profili karşısında işletmeler yaşanabilecek hizmet hataları konusunda daha fazla hassasiyet göstermelidirler.

Yaşanılan hizmet hatalarının türüne bakıldığında ise, en göze çarpanı \%10'luk bir oranla diğer müşterilerin aşırı gürültülü olmaları ve $\% 8,3$ ile yiyecek alternatiflerinin yetersizliği olmaktadır. Bunları \%5,5'lik bir oranla temizlik ve hijyen problemleri, net olmayan işletme politikaları, beklentilerin doğru anlaşılamaması ve diğer müşterilerin rahatsız edici tüketim davranışları takip etmektedir. Bu veriler de diğer verileri destekler nitelikte ve yönetimsel yetersizliklere dikkat çekmektedir.

Yaşanılan hizmet hatası sonrası uygulanan telafi yöntemleri sırasıyla; \%17,4 ile özür dilenmesi ve hatanın hemen giderilmesi, \%14,5 ile sadece özür dilenmesi, \%10,9 ile oda değişikliği yapılması, $\% 6,4$ ile ücretli olan hizmetlerin bazılarının hediye edilmesi, $\% 5,5$ ile şikâyetin bir üst makama yönlendirilmesi, \%3,6 ile odaya özel servislerin yapılması, \%2,7 ile ücrette indirim yapılması ve $\% 1,8$ ile hiç ücret alınmamasıdır. \%18,1 oranında bunların dışında telafi yöntemleri uygulanırken \%15,5 oranında telafi yöntemlerinin hiçbiri uygulanmamıştır. \%15,5 oranında işletmenin hizmet hataları karşısında tepkisiz kalması, \%15,5 oranında ikinci defa memnuniyetsizlik yaşayan müşteri demektir. Çünkü hata sonrasında müşterilerde işletmeden telafi edici bir yaklaşım beklentisi doğmaktadır. Hiçbir şeyin yapılmaması ise zaten memnuniyetsiz olan müşterilerin ikinci defa memnuniyetsizlik yaşaması anlamına gelmektedir (çifte sapma durumu). Bu durumdaki müşteri, memnuniyetsizliğini daha sesli hale getirecek ve olumsuz ağızdan ağıza pazarlama süreci başlayacaktır.

Uygulanan telafi yönteminin müşteri memnuniyetine etkisini belirlemeye yönelik sorulan soruya katılımciların \%48,2'si telafinin olması gerektiği gibi asgari düzeyde olduğu, \% 38,2'si yetersiz olduğu ve yalnızca \%13,6'sı ise telafi yönteminin yeterli olduğu ve büyük keyif aldığı yönünde cevap vermişlerdir. Bu durumda hizmet hatasından kaynaklı müşteri memnuniyetsizliğinin yalnızca \%13,6'sının tamamen giderilip dezavantajlı durumun avantaja dönüştürülebildiğini söylemek mümkündür. Bu durum aynı zamanda müşterilerin $\% 38,2$ 'sinin memnuniyetsiz bir şekilde işletmeden ayrıldığını ve $\% 48,2^{\prime}$ sinin ise tam olarak memnuniyet elde etmeden ve aldığ 1 hizmetten tatmin olmadan işletmeden ayrıldığını ifade etmektedir.

Katılımclara telafi yöntemi sonrasında işletmeye karşı tutumları sorulduğunda, \%45,5'i hizmet hatası sonucu oluşan olumsuz algıda hiçbir değişiklik olmadığını ve hatta \%25,4'i daha da olumsuz olduğunu ifade etmiştir. Katılımcıların yalnızca \%29,1'i işletmeye yönelik tutumlarının hizmet telafisi sonrasında daha olumlu olduğunu belirtmiştir. Bu durum, uygulanan hizmet telafisi uygulamalarının yetersizliğini göstermektedir. Katılımcıların uygulanan telafi sonrasında daha da olumsuz algılara sahip olması ise, müşterilerin beklentileri ile uyuşmayan yanlış telafi yöntemlerinin uygulandığını ortaya koymaktadır.

Katılımcılar aynı zamanda yaşanılan hizmet hatalarından sonra \%61,8 oranında o işletmeye güven duymadıklarını belirtmişler ve $\% 60,9$ oranında aynı işletmeyi bir daha tercih etmeyeceklerini ifade etmişlerdir. Bu oranların oldukça yüksek olması, müşteri memnuniyeti açısından hizmet telafilerinin ne kadar önemli olduğunu ortaya koymaktadır.

Son olarak, hizmet hatalarının ve hizmet telafisi yöntemlerinin müşteri memnuniyeti üzerindeki etkisini belirlemeye yönelik yapılan regresyon analizinde, her iki boyutun da müşteri memnuniyeti üzerinde etkisi olduğu görülmüştür ve çalışmanın tüm hipotezleri (H1a, H1b, H1c, $\mathrm{H} 2 \mathrm{a}, \mathrm{H} 2 \mathrm{~b}, \mathrm{H} 2 \mathrm{c}, \mathrm{H} 2 \mathrm{~d}$ ) desteklenmiştir. Hizmet hatalarının etkisi negatif yöndeyken hizmet telafi yöntemlerinin ise etkisi pozitif yöndedir. Dolayısı ile hizmet hatalarının müşteri memnuniyetini azalttığı ve hizmet telafisi uygulamalarının ise müşteri memnuniyetini arttırdığı söylenebilir. 
Burada önemli olan husus, en büyük etkiyi "telafi etme çabalarının" ve en düşük etkiyi ise "yalnızca özür dilemenin" yaratmış olmasıdır. Buradan anlaşılacağı üzere, müşteriler yaşadıkları hizmet hatalarının sonucunda işletmelerden yalnızca özür dilemek ve hatayı telafi etmenin ötesinde bir takım ayrıcalıklar beklemektedir. Özellikle rekabetin oldukça yoğun yaşandığı turizm işletmelerinde, hizmet hataları sonucunda müşterilerin kaybedilmemesi için etkili ve müşterilerin beklentilerine uygun telafi yöntemlerinin seçilmesi ve uygulanması, aynı zamanda hataların tekrarlanmaması açısından yönetimsel planlamaların yapılması ve politikaların oluşturulması gerekmektedir.

Günümüz pazarlama anlayışında, tutundurma karması elemanlarının iletişim boyutlarının öncelik kazanması sonucunda bütünleşik pazarlama iletişimi kapsamında müşteri ve işletme arasında karşılıklı ilişkilerin kurulması ve etkileşimin sağlanması oldukça önemli hale gelmiştir. Hizmet telafisi stratejileri belirlenirken bu hususun dikkate alınması oldukça önemlidir. Çünkü hizmet telafisi uygulamaları ile aynı zamanda işletmeler doğrudan müşteriler ile iletişim kurarak karşılıklı bir etkileşim yaratma ve işletme hakkında oluşan olumsuz algıyı tam tersine çevirerek daha olumlu bir imaj oluşturma imkânı da elde etmektedirler. Özellikle mal ve hizmetler arasındaki farklılıkların oldukça azaldığı ve dolayısıyla rekabetin yoğun yaşandığı turizm işletmelerinde müşteriler ayrıcalıklı hizmetler beklemekte ve işletmenin sunacağı ayrıcalıklı hizmetler satın alma kararlarını yönlendirmektedir. Ayrıcalıklı hizmet beklentisi ile turizm işletmesine gelen ve karşılaşılan hizmet hataları sonucunda memnuniyetsizlik yaşayan günümüz bilinçli tüketici profili karşısında işletmelerin daha etkili telafi yöntemleri uygulamaları ve müşterilerdeki olumsuz algıyı ortadan kaldırmak için samimi bir gayret göstermeleri gerekmektedir. Aksi halde müşterilerin tepkisi işletme içerisinde kalmamakta, sosyal medya üzerinde işletmeye yönelik olumsuz yorumlar, paylaşımlar, şikâyetler ve hatta yasal işlemler söz konusu olabilmektedir. Müşteriler için yalnızca özür dilemek memnuniyetsizliğin telafisi için yeterli gelmemekte, müşteriler özellikle işletme yönetiminin hatanın telafisi için daha samimi bir gayret içerisinde olduğunu görmek istemektedir. Yöneticilerin olaylar karşısındaki duruşları, yaklaşımları, memnuniyetsiz müşteriler ile iletişime geçme biçimleri ve problemin çözümüne yönelik hızlı reaksiyon gösterip göstermemeleri hizmet telafisi sürecinin başarısını belirlemektedir. Aynı zamanda, hizmet kalitesini sürekli arttırmak, çalışanları sürekli eğitmek, problem çözme becerileri kazanmalarını sağlamak, diğer müşterilerin de hizmet hatalarına sebebiyet vermemeleri için çok net işletme politikaları ve sinırlamalar oluşturmak hizmet hatalarının yaşanmaması için alınması gereken önlemlerdir. Unutulmamalıdır ki kaybedilmiş her bir müşteri, aynı zamanda kaybedilmiş birçok potansiyel müşteri anlamına gelmektedir.

\section{KAYNAKÇA}

Bell, C. R. and Zemke, R. E. (1987). Service Breakdown: The Road to Recovery. Management Review, 76(10), 32-35.

Bitner, M.J., Booms, B.H. and Mohr, L.A. (1994). Critical Service Encounters: The Employee's Viewpoint. Journal of Marketing, 58(4), 95-106.

Bitner, M.J., Booms, B.H. and Tetreault, M.S. (1990). The Service Encounter: Diagnosing Favorable and Unfavorable Incidents. Journal of Marketing, 54(1), 71-84.

Boshoff. C. and Staude, G. (2003). Satisfaction with Service Recovery: Its Measurement and Its Outcomes. South African Journal of Business Management, 34(3), 9-16.

Bozkaya, T, A (2012). Bankacılık Sektöründe Hizmet Hatası ve Hizmet Telafisi. Yayınlanmış Yüksek Lisans Tezi, Balıkesir Üniversitesi Sosyal Bilimler Enstitüsü, Balıkesir. 
Çalışkan, O. (2013). Restoran İşletmelerinde Hizmet Hataları, Hizmet Telafi Stratejileri ve Müşteri Memnuniyeti İlişkisi. Journal of Travel and Hospitality Management, 10 (3), 65-83.

Cengiz, E., Akdu, S. ve Bostan, M.K. (2015). Sağlık Hizmetlerinde Hizmet Hatası Telafi Stratejileri. Gümüşhane Üniversitesi Sosyal Bilimler Elektronik Dergisi, 12, 87-101.

Chua, B.L., Othman, M., Boo, H.C., Abkarim, M.S. and Ramachandran, S. (2010). Servicescape Failure and Recovery Strategy in the Fast Food Service Industry: The Effect of Costumer Repatronization. Journal of Quality Assurance in Hospitality and Tourism, 11(3), 179-198.

Cinar, B. and Koç, F. (2018). The Effects of Servıce Failures Types on Satisfaction, Trust, and Intention to Complain. Press Academia Procedia, 7, 159-164.

Cranage, D.A. and Mattila, A.S. (2006). Service Recovery and Pre-Emptive Strategies for Service Failure: Both Lead to Customer Satisfaction and Loyalty, But for Different Reasons. Journal of Hospitality and Leisure Marketing, 13(3-4), 161-181.

Davidow, M. (2003). Organisational Responses to Customer Complaints: What Works and What Doesn't. Journal of Service Research, 5(3), 225-250.

Eccles, G. and Durand, P. (1998). Complaining Costumers, Service Recovery and Continuous Improvement. Managing Service Quality, 8(1), 68-71.

Fierro, J.C., Pineda, J.M.B., Benitez R.R. and Carroso, R. V. (2013). Analysis of the Moderating Role of the Gender Variable in Service Recovery Processes. Journal of Retailing and Consumer Services, 20(3), 408-418.

Forbes, L.P., Kelley, S.W. and Hoffman, K.D. (2005). Typologies of E-Commerce Retail Failures and Recovery Strategies. Journal of Services Marketing, 19(5), 280-292.

Fu, Y.Y. and Mount, D. (2007). Hotel Guests' Cumulative Satisfaction Updating Process in the Context of Service Failure and Service Recovery. International Journal of Hospitality and Tourism Administration, 8(1), 77-98.

Gordon, H.G., Mcdougall, T.J. and Levesque, J. (1999). Waiting for Service: The Effectiveness of Recovery Strategies. International Journal of Contemporary Hospitality Management, 11(1), 6-15.

Ha, J. and Jang, S. (2009). Perceived Justice in Service Recovery and Behavioral Intentions: The Role of Relationship Quality. International Journal of Hospitality Management, 28, 319-327.

Hart, C., Heskett, J. and Sasser, E. (1990). The Profitable Art of Service Recovery. Harvard Business Review, 68(4), 148-156.

Hocutt, M.A., Bowers, M.R. and Donovan, D.T. (2006). The Art of Service Recovery: Fact or Fiction?. Journal of Services Marketing, 20(3), 199-207.

Hoffman, K.D. and Kelley, S.W. (2000). Perceived Justice Needs and Recovery Evaluation: A Contingency Approach. European Journal of Marketing, 34(3/4), 418-433.

Hoffman, K.D., Kelley, S.W. and Rotalsky, H.M. (1995). Tracking Service Failures and Employee Recovery Efforts. Journal of Services Marketing, 9(2), 49-61.

Iglesias, V. (2009). The Attribution of Service Failures: Effects on Consumer Satisfaction. Service Industries Journal, 29 (2), 127-141.

Kambur, E. (2018). Müşterilerin Hizmet Hatası ve Hizmet Telafisine Yönelik Algılarının Demografik Özellikler Doğrultusunda Tespit Edilmesi. Akademik Bakış Dergisi, 69, 49-68. 
Kelley, S.W., Hoffman, K.D. and Davis, M.A. (1993). A Typology of Retail Failures and Recoveries. Journal of Retail, 69(4), 429-452.

Keiningham, T., Morgeson, F., Aksoy, L. and Williams, L. (2014). Service Failure Severity, Customer Satisfaction and Marker Share an Examination of the Airline Industry. Journal of Service Research, 17(4), 415-431.

Kim, G.K., Wang, C. and Mattila, A.S. (2010). The Relationship between Consumer Complaining Behavior and Service Recovery: An Integrative Review. International Journal of Contemporary Hospitality Management, 7(22), 975- 991.

Kim, J.H. and Jang, S.C. (2014). The Fading Affect Bias: Examining Changes in Affect and Behavioral Intentions in Restaurant Service Failures and Recoveries. International Journal of Hospitality Management, 40, 109-119.

Kim, T., Kim, W.G. and Kim, H. (2009). The Effects of Perceived Justice on Recovery Satisfaction, trust, word of mouth, and Revisit Intention in Upscale Hotels. Tourism Management, 30, 51-62.

Levesque, T.J. and McDougall, G.H.G. (2000). Service Problems and Recovery Strategies: An Experiment Can. Journal of Administrative Science, 17(1), 20-37.

Lewis, B.R. and McCann, P. (2004). Service Failure and Recovery: Evidence from The Hotel Industry. International Journal of Contemporary Hospitality Management, 16(1), 6-17.

Li, D., Li, Z. and Peng, X. (2011). Moderating Effect of Service Failure on the Relationship Between Service Recovery and Customer Satisfaction: Evidence from Online Shopping. Contemporary Logistics, 05, 91-95.

Lii, Y.S., Pant, A. and Lee, M. (2012). Balancing the scales: recovering from service failures depends on the psychological distance of consumers. The Service Industries Journal, 32(11), 17751790.

Liu, T.C., Warden, C.A., Lee, C.H. and Huang, C.T. (2001). Fatal Service Failures Across Cultures. Journal of Hospitality and Leisure Marketing, 8(1-2), 93-111.

Mattila, A.S. (1999). An Examination of Factors Affecting Service Recovery in a Restaurant Setting. Journal of Hospitality and Tourism Research, 23(3), 284-298.

Mattila, A.S. and Cranage, D. (2005). The Impact of Choice on Fairness in the Context of Service Recovery. Journal of Services Marketing, 19(5), 271-279.

Mattila, A.S. and Patterson, P.G. (2004). Service Recovery and Fairness Perceptions in Collectivist and Individualist Contexts. Journal of Service Research, 6(4), 336-346.

Maxham, J.G. and Netemeyer, R.G. (2002). A Longitudinal Study of Complaining Customers' Evaluations of Multiple Service Failures and Recovery Efforts. Journal of Marketing, 66(4), 57-71.

Miller, J.L., Craighead, C.W. and Karwan, K.R. (2000). Service Recovery: A Framework and Empirical İnvestigation. Journal of Operations Management, 18(4), 387-400.

Mostafa, R., Lages, C.R. and Saaksjarvi, M. (2014). The CURE scale: a multidimensional measure of service recovery strategy. Journal of Services Marketing, 28 (4), 300-310.

Mueller, R.D., Palmer, A., Mack, R. and McMullan, R. (2003). Service in the Restaurant Industry: An American and Irish Comparasion of Service Failures and Recovery Strategies. Hospitality Management, 22, 395-418.

Noone, B.M. (2012). Overcompensating for Severe Service Failure: Perceived Fairness and Effect on Negative Word of Mouth Intent. Journal of Services Marketing, 26(5), 342-351. 
Ok, C., Back, K.J. and Shanklin, C.W. (2006). Service Recovery Paradox: Implications from an Experimental Study in a Restaurant Setting. Journal of Hospitality \& Leisure Marketing, 3(14), 17-31.

Olcay, A. ve Özekinci, Y.K. (2015). Yiyecek-İçecek İşletmelerinde Hizmet Hataları, Telafi Yöntemleri ve Müşteri Memnuniyeti İlişkisi (Gaziantep Örneği). Uluslararası Sosyal Araştırmalar Dergisi, 8(41), 1254-1268.

Özdemir, H. ve Avc1, M.S. (2019). Müşteri Affeder mi? (Zincir Süpermarketlerde Hizmet Hataları Ve Telafileri Üzerine Nitel Bir Araştırma). Üçüncü Sektör Sosyal Ekonomi Dergisi, 54(1), 549-564.

Palmer, A. (2001). Principles of Services Marketing (3rd Edition). McGraw-Hill: Singapore.

Phau, I. and Ferguson, G. (2013). Validating the Customer Satisfaction Survey (CSS) Scale in the Australian fast food industry. Australasian Marketing Journal, 21,147-154.

Smith, A. K. and Bolton, R.N. (1998). An Experimental Investigation of Costumer Reactions To Recovery Encounters: Paradox and Peril?. Journal of Service Research, 36(3), 356-372.

Smith, A.K., Bolton, R.N. and Wagner, J. (1999). A Model of Customer Satisfaction with Service Encounters involving Failure and Recovery. Journal of Marketing Research, 36(3), 356-372.

Spreng, R.A., Harell, G.D. and Mackoy, R.D. (1995). Service Recovery: Impact on Satisfaction and Intentions. Journal of Services Marketing, 9(1), 15-23.

Stratemeyer, A. W., Geringer, C.D. and Canton, A. (2014). An Exploratory Investigation of the Effects of Service Failures and Recovery Efforts on Customer Satisfaction. American Journal of Management, 14(3),20-28.

Tax, S.S., Brown, S.W. and Chandrashekaran, M. (1998). Costumer Evaluations of Service Complaint Experiences: Implications for Relationship Marketing. Journal of Marketing, 62(4), 6076.

Tsai, C. and Su, C.S. (2009). Service Failures and Recovery Strategies of Chain Restaurants in Taiwan. The Service Industries Journal, 29(12), 1779-1796.

Warden, C.A., Huang, C.T., Stephen, C.T. and Chen, J.F. (2008). Restaurant Service Failure Recoveries: Role Expectations in a Chinese Cultural Setting. Journal of Hospitality and Leisure Marketing, 16(1-2), 159-180.

Warden, C.A., Liu, T.C., Huang, C.T. and Lee, C.H. (2003). Service Failures Away from Home: Benefits in Intercultural Encounters. International Journal of Service Industry Management, 14(4), 436-456.

Wirtz, J. and Mattila, A.S. (2004). Costumer Responses to Compensation, Speed of Recovery and Apology after a Service. International Journal of Service Industry Management, 15(2), 150-166.

Zeithaml, V.A. and Bitner, M.J. (2003). Services Marketing, McGraw-Hill: New York.

Zeithaml, V.A., Berry, L.L. and Parasuraman, A. (1990). Delivering Quality Service: Balancing Customer Perceptions and Expectations. The Free Press: New York.

Zulhan, O., Mohd, S., Mohd, Z. and Salleh, M.R. (2013). Costumer Behavioral Intention: Influence of Service Delivery Failures and Service Recovery in Malay Restaurants. Procedia - Social and Behavioral Sciences, 105, 115-121. 